\title{
СТРАТЕГІЯ ПРОВЕДЕННЯ РЕАБІЛІТАЦІЙНИХ ЗАХОДІВ У ПАЦІЄНТІВ ПОХИЛОГО ВІКУ 3 ПЕРВИННИМ ГОНАРТРОЗОМ
}

ДВНЗ «Тернопільський державний медичний університет імені І.Я. Горбачевського МОЗ України», м. Тернопіль, Україна

\begin{abstract}
Мета: визначити стратегію проведення медичної реабілітації у хворих на первинний гонартроз у похилому віці 3 обґрунтуванням вибору реабілітаційних заходів.

Матеріали і методи. Проведено реалізацію програми реабілітації за результатами організаційного експерименту на базі реабілітаційного відділення та санаторного закладу під час проведення медичної реабілітації 112 пацієнтам похилого віку з первинним гонартрозом. Використано дані клініко-реабілітаційної характеристики пацієнтів.

Результати. Проаналізовано результати впровадження алгоритму стратегії проведення реабілітаційних заходів та вивчено ефрективність проведення реабілітації: спостерігали позитивну динаміку рухової активності після проведеної реабілітації у $(92,4 \pm 4,2) \%$ досліджуваних хворих, у контрольній групі в $(41,4 \pm 2,2) \%$, якість життя покращилася після проведення реабілітації у $(66,3 \pm 2,8) \%$ пацієнтів, у контрольній групі в $(35,7 \pm 1,7) \%$ що підтверджує ефективність запропонованого алгоритму.

Висновки. Застосування запропонованого алгоритму стратегії проведення реабілітаційних заходів дозволяє вирішувати основні завдання реабілітації, сумує ризики та їх можливі корекції, забезпечує індивідуальний підхід та оптимізацію відновного лікування, підвищуючи доступність та якість медичних послуг при ефективнішому та раціональнішому використанні методів реабілітації.
\end{abstract}

КЛЮЧОВІ СЛОВА: медична реабілітація, первинний гонартроз, стратегія, реабілітаційні заходи.

Остеоартроз (ОА) є одним із найпоширеніших захворювань опорно-рухового апарату, особливо в осіб старшої вікової групи (у кожної третьої літньої людини, досягаючи 70 \% серед осіб, старших 65 років) [3]. Проблема ефективного лікування та реабілітації ОА має не тільки медико-соціальне, але й економічне значення [4]. Тому необхідні нові підходи для організації реабілітаційних заходів у хворих на ОА, особливо в похилому віці.

На сьогодні після виписування зі стаціонару пацієнти тільки в 26 \% випадків продовжують відновне лікування в амбулаторних умовах, 15 \% в санаторно-курортних закладах [1].

В Україні існує декілька організаційних фрорм проведення відновного лікування - монопрофрільні відділення медичної реабілітації у складі колишніх дільничних лікарень, багатопрофрільні відділення у складі ЦРЛ, потужні науково-дослідні центри та санаторно-курортні заклади [5].

На ранньому етапі реабілітації чільне місце займає етіопатогенетична та симптоматична фрармакотерапія, на пізньому неспециорічна, спрямована на підвищення загальної опірності організму.

Актуальність проблеми диктує необхідність розроблення нових та удосконалення вже існуючих методів обстеження та реабілітації з впровадженням стратегії проведення реабілітаційних заходів у пацієнтів вказаного профрілю. Подальший (с) Г.О. Сірант, 2017 розвиток системи ефрективної медичної реабілітації з урахуванням сучасного рівня суспільного здоров'я, без сумніву, можна віднести до числа найважливіших медико-соціальних завдань сучасної охорони здоров'я.

Мета дослідження: визначити стратегію проведення медичної реабілітації у хворих на первинний гонартроз (ПГА) у похилому віці з обґрунтуванням вибору реабілітаційних заходів.

Матеріали і методи. Набутий досвід свідчить, що завдання відновного лікування вирішуються найбільш повно, якщо здійснюється єдина стратегія та тактика реабілітаційних заходів. На сьогодні цілковито очевидно, що основними принципами цього процесу є ранній початок, використання всіх видів реабілітації (медичної, психологічної, соціальної та ін.), безперервність та наступність між її фразами (етапами) [2].

На основі власних науково-практичних розробок із проблем організації реабілітації ми розробили алгоритм стратегії проведення медичної реабілітації у хворих на ПГА в похилому віці, який включає певну послідовність дій на початку реабілітації 3 урахуванням оцінки структурно-орункціональних змін суглобів, визначення клініко-патогенетичного варіанта перебігу патологічного процесу, інтегрального стану пацієнта, обґрунтованості диференційованого підходу до вибору реабілітаційних та профрілактичних заходів (рис. 1). 


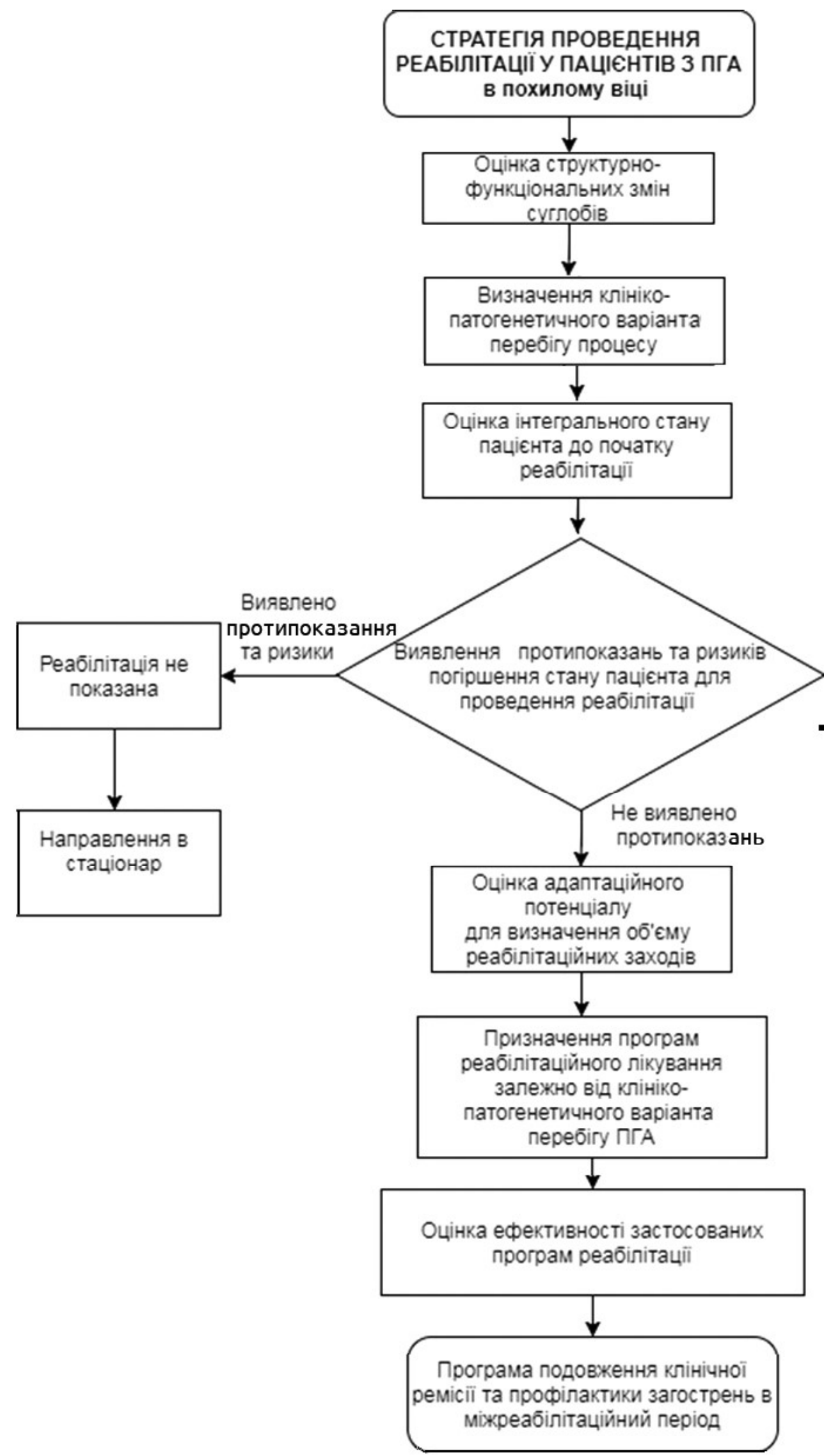

Puc. 1. Стратегія проведення медичної реабілітації у пацієнтів на ПгА в похилому віці. 
Реалізацію розробленого алгоритму реабілітації провели за результатами організаційного експерименту на базі реабілітаційного відділення КНП «Міська комунальна лікарня № 3» ТМР та санаторію «Медобори» Тернопільської області під час проведення медичної реабілітації 112 пацієнтам похилого віку з ПГА (І (основна) група). У II (контрольній) групі було 30 пацієнтів на ПГА, яким проводили медичну реабілітацію, відповідно до уніфрікованого клінічного протоколу [7]. Пацієнти, включені в дослідження, були обстежені за єдиною програмою, до складу якої входили загальноклінічні, фрункціональні, лабораторні, рентгенологічні та інструментальні методи. Наявність симптомів ПГА оцінювали згідно з рекомендаціями Європейської антиревматичної ліги (EULAR) за стандартами артрологічного статусу: оцінка болю в спокої та при рухах за візуальною аналоговою шкалою (ВАШ), індекс визначення ступеня тяжкості гонартрозу (індекс Лекена), альгофункціональний індекс WOMAC (Western Ontario \& McMaster Universities Osteoarthritis Index) та анкета оцінки здоров'я HAQ (Health Assessment Questionnaire).
При розробці індивідуальних програм реабілітації хворих на ПГА враховували адаптаційний потенціал організму, стан компенсації, функціональні обмеження з боку опорно-рухового апарату, характер супутньої соматичної патології. В програмі реабілітації використовували різні форми немедикаментозних впливів: дієтотерапія, кінезіотерапія, фрізіотерапія, механотерапія, бальнеотерапія, пелоїдотерапія. Лікувальні засоби призначали за показаннями. Завданнями психологічного супроводу медичної реабілітації є вироблення у пацієнта мотивації на участь в реабілітаційному процесі.

Результати дослідження та їх обговорення. Критерії якості лікування ОА $[2,6]$ включають: відсутність або істотне зменшення проявів суглобового синдрому, відсутність рецидивів синовіту, уповільнення рентгенологічного прогресування процесу, деструктивних змін суглобового хряща (за даними ультразвукового дослідження суглобів, MPT), поліпшення якості життя пацієнта. Результати спостереження наведено в таблиці.

Отримані результати дослідження свідчать про позитивний вплив розроблених індивідуальних

Таблиця. Динаміка даних анкетування пацієнтів похилого віку на ПГА при проведенні медичної реабілітації

\begin{tabular}{|c|c|c|c|c|c|c|}
\hline \multirow{2}{*}{ Показник } & \multicolumn{3}{|c|}{ Пацієнти I групи (n=112) } & \multicolumn{3}{c|}{ Пацієнти II групи (n=30) } \\
\cline { 2 - 7 } & $\begin{array}{c}\text { 1 дослі- } \\
\text { дження }\end{array}$ & $\begin{array}{c}2 \text { (чере3 } \\
2 \text { тижні) }\end{array}$ & $\begin{array}{c}3 \text { (через } \\
6 \text { місяців) }\end{array}$ & $\begin{array}{c}\text { 1 дослі- } \\
\text { дження }\end{array}$ & $\begin{array}{c}2 \text { (через } \\
2 \text { тижні) }\end{array}$ & $\begin{array}{c}3 \text { (через } \\
6 \text { місяців) }\end{array}$ \\
\hline $\begin{array}{c}\text { Сумарний індекс } \\
\text { WOМАC, бали }\end{array}$ & $59,3 \pm 2,4$ & $39,7 \pm 1,6^{\mathrm{a}}$ & $46,2 \pm 2,1^{\mathrm{a}}$ & $58,3 \pm 2,5$ & $46,4 \pm 2,2^{\mathrm{a}}$ & $57,8 \pm 2,4$ \\
\hline Індекс НАQ, бали & $20,4 \pm 0,6$ & $16,2 \pm 0,7^{\mathrm{a}}$ & $17,5 \pm 0,8^{\mathrm{a}}$ & $20,5 \pm 0,9$ & $18,3 \pm 0,7^{\mathrm{a}}$ & $19,6 \pm 0,8$ \\
\hline
\end{tabular}

Примітка. ${ }^{\text {a }}$ різниця статистично значуща $(p<0,05)$ після лікування між групами.

реабілітаційних комплексів на основі дотримання алгоритму стратегії проведення реабілітації: покращення якості життя пацієнтів як відразу після закінчення етапу медичної реабілітації, так і через 6 місяців: підвищилася повсякденна активність, суттєво зменшилися біль в суглобах та почуття тривоги. В I групі якість життя покращилася після проведення реабілітації у $(66,3 \pm 2,8) \%$ пацієнтів, через 6 місяців - у $(70,2 \pm 3,5) \%$; стан без змін був зареєстрований у $(32,8 \pm 1,4) \%$ відразу після проведеної реабілітації і у $(22,2 \pm 1,1) \%$ через 6 місяців. Погіршення стану після проведеної реабілітації не зареєстровано. Водночас після проведення стандартної схеми реабілітації якість життя покращилася в II групі у $(35,7 \pm 1,7) \%$, через 6 місяців вираження больового синдрому та порушення фрункції суглобів повернулись до вихідних значень у $(54,2 \pm 2,2) \%$, а в $(32,2 \pm 1,4) \%$ пацієнтів вони перевершили ці показники.

Позитивна динаміка клінічної симптоматики в основній групі супроводжувалась збільшенням амплітуди рухів у колінному суглобі на $(29,2 \pm 1,7) \%$, у той час, як у контрольній групі - на $(14,3 \pm 0,8) \%$.
Також при застосуванні алгоритму стратегії медичної реабілітації у пацієнтів похилого віку з ПГА спостерігали позитивну динаміку рухової активності після проведеної реабілітації у $(92,4 \pm 4,2) \%$ досліджуваних хворих, в контрольній групі у $(41,4 \pm 2,2) \%$, що підтверджує ефективність запропонованого алгоритму.

Головною перевагою застосування стратегії реабілітації є можливість задовольняти потреби хворих у реабілітаційній допомозі, здійснювати контроль за якістю реабілітації за даними лабораторних, клінічних, фрункціональних та інших досліджень, широко застосовувати природні та пресрормовані фрізичні фрактори, медикаментозну терапію, здійснювати консультації хворих спеціалістами, комплексно відновлювати здоров'я хворих, використовуючи нетрадиційні методи лікування. Все перераховане дозволяє реалізувати комплекс реабілітаційних засобів в оптимальному об'ємі та в необхідній послідовності, забезпечити наступність лікувальних та реабілітаційних заходів, індивідуальний підхід до лікування хворого, а також суттєво підвищити медичну та економічну ефективність відновного лікування. 


\section{Висновки}

Застосування запропонованого алгоритму стратегії проведення реабілітаційних заходів дозволяє вирішувати основні завдання реабілітації, сумує ризики та їх можливі корекції, забезпечує індивідуальний підхід та оптимізацію відновного лікування, підвищуючи доступність та якість медичних послуг при ефективнішому та раціональнішому використанні методів реабілітації.

Перспективи подальших досліджень спрямовані на вивчення прогнозування можливості виникнення та попередження розвитку первинного остеоартрозу, проведення ранньої реабілітації. Подальша робота в цьому напрямку доцільна та економічно виправдана.

\section{Список літератури}

1. Голяченко А. О. Медична реабілітація в санаторних умовах / А. О. Голяченко, В. І. Мартинюк, Т. Г. Бакалюк // Вісник наукових досліджень. - 2007. - № 4. - С. 8-9.

2. Золотарева Т. А. Медицинская реабилитация / Т. А. Золотарева, К. Д. Бабов. - К. : КИМ, 2012. - 496 с.

3. Казимирко В. К. Инволюционный остеоартроз и остеопороз / В. К. Казимирко, В. Н. Коваленко, В. В. Флегонтова. Донецк : Издатель Заславский А. Ю., 2011. - 722 с.

4. Коваленко В. М. Остеоартроз. Практичнанастанова:дипломний проект (робота)/В. М. Коваленко, О. П. Борткевич. 3-тє вид., доповн., зі змінами. - К. : МОРІОН, 2010. - 608 с.

5. Сергієні О. В. Організація та управління системою медичної реабілітації інвалідів : методичні рекомендації / О. В. Сергієні. - Дніпропетровськ, 2006. - 28 с.

6. EULAR evidence-based recommendations for the diagnosis of knee osteoarthritis / W. Zhang, M. Doherty, G. Peat [et al.] // Ann. Rheum. Dis. - 2010. - Vol. 69. - P. 483-489.

7.http://www.webmedfamily.org/index.php/normativnaya-baza/mediko-tekhnologicheskaya-dokumentatsiya/882-unifikovanijklinichnij-protokol-medichnoji-dopomogi-pri-osteoartrozi.

\section{References}

1. Holiachenko, A.O., Martyniuk, V.I., \& Bakaliuk, T.H. (2007). Medychna reabilitatsiia v sanatornykh umovakh [Medical rehabilitation in sanatorium conditions]. Visnyk naukovykh doslidzhen - Journal of Scientific Research, 4, 8-9 [in Ukrainian]. 2. Zolotareva, T.A. \& Babov, K.D. (2012). Meditsinskaya reabilitatsiya [Medical rehabilitation]. Kyiv: KIM [in Russian].

3. Kazymyrko, V. K., Kovalenko, V. N. \& Flegontova, V. V. (2011). Involyutsionnyy osteoartroz i osteoporoz [Involutional osteoarthritis and osteoporosis]. Donetsk: Izdatel Zaslavskyy A.Yu. [in Russian].

4. Kovalenko, V. M. \& Bortkevich, V.M. (2010). Osteoartroz. Praktychna nastanova: dyplomnyi proekt (robota) [Practical guidance: graduation project (work)]. (3nd ed., rev.). Kyiv: MORION [in Ukrainian].

5. Serhiieni, O.V. (2006). Orhanizatsiia ta upravlinnia systemoiu medychnoi reabilitatsii invalidiv. Metod. Rekomendatsii [Organization and management of the system of medical rehabilitation of the disabled. Guidelines]. Dnipropetrovsk [in Ukrainian].

6. Zhang, W., Doherty, M., \& Peat, G. (2010). EULAR evidence-based recommendations for the diagnosis of knee osteoarthritis. Ann. Rheum. Dis., 69, 483-489.

7.http://www.webmedfamily.org/index.php/normativnaya-baza/mediko-tekhnologicheskaya-dokumentatsiya/882-unifikovanijklinichnij-protokol-medichnoji-dopomogi-pri-osteoartrozi.

\section{СТРАТЕГИЯ ПРОВЕДЕНИЯ РЕАБИЛИТАЦИОННЫХ МЕРОПРИЯТИЙ У ПАЦИЕНТОВ ПОЖИЛОГО ВОЗРАСТА С ПЕРВИЧНЫМ ГОНАРТРОЗОМ \\ Г.О. Сирант}

ГВУЗ «Тернопольский государственный медицинский университет имени И.Я. Горбачевского МЗ Украины»,

г. Тернополь, Украина

Цель: определить стратегию проведения медицинской реабилитации у больных первичным гонартрозом в пожилом возрасте с обоснованием выбора реабилитационных мероприятий.

Материалы и методы. Реализацию программы реабилитации провели по результатам организационного эксперимента на базе реабилитационного отделения и санаторного учреждения при проведении медицинской реабилитации 112 пациентов пожилого возраста с первичным гонартрозом. Использованы данные клиникореабилитационной характеристики пациентов.

Результаты. Проанализированы результаты внедрения алгоритма стратегии проведения реабилитационных мероприятий и изучена эффрективность проведения реабилитации: наблюдалась положительная динамика двигательной активности после проведенной реабилитации в $(92,4 \pm 4,2) \%$ исследуемых больных, в контрольной группе в $(41,4 \pm 2,2) \%$, качество жизни улучшилось после проведения реабилитации в $(66,3 \pm 2,8)$ \% пациентов, в контрольной группе в $(35,7 \pm 1,7) \%$, что подтверждает эфрфективность предложенного алгоритма.

Выводы. Применение предложенного алгоритма стратегии проведения реабилитационных мероприятий позволяет решать основные задачи реабилитации, суммирует риски и их возможные коррекции, обеспечивает индивидуальный подход и оптимизацию восстановительного лечения, повышая доступность и качество медицинских услуг при эффективном и рациональном использовании методов реабилитации. 
КЛЮЧЕВЫЕ СЛОВА: медицинская реабилитация; первичный гонартроз; стратегия; реабилитационные мероприятия.

\section{STRATEGY OF REHABILITATION MEASURES IN ELDERLY PATIENTS WITH PRIMARY GONARTHRITIS}

H.O. Sirant

I. Horbachevsky Ternopil State Medical University

Purpose: determining the strategy of medical rehabilitation in patients with primary gonarthritis in the elderly with a justification of the choice of rehabilitation measures.

Materials and Methods. Implementation of the rehabilitation program was carried out according to the results of an organizational experiment based on rehabilitation department and sanatorium during the medical rehabilitation of 112 elderly patients with primary gonarthritis. The clinical and rehabilitation characteristics of patients were used.

Results. The results of rehabilitation strategy implementation were analyzed and the effectiveness of rehabilitation was studied: there was a positive dynamics of motor activity after rehabilitation in $(92.4 \pm 4.2) \%$ of the patients under study, in the control group $(41.4 \pm 2.2) \%$, quality of life improved after rehabilitation in $(66.3 \pm 2.8) \%$ of patients, in the control group $(35.7 \pm 1.7) \%$, which confirms the effectiveness of the proposed algorithm.

Conclusions. The application of the strategy proposed algorithm of rehabilitation measures allows to solve the main tasks of rehabilitation, misses the risks and their possible corrections, provides an individual approach and optimization of rehabilitation, increasing the accessibility and quality of medical services by more efficient and rational use of rehabilitation methods.

KEY WORDS: medical rehabilitation; primary gonarthritis; strategy; rehabilitation measures.

Рукопис надійшов до редакції 29.09.2017 p.

\section{Відомості про автора:}

Сірант Галина Олегівна - асистент кафедри медичної реабілітації ДВНЗ «Тернопільський державний медичний університет імені І.Я. Горбачевського МОЗ України»; тел. +38(098) 836-41-64. 